Research article

\title{
Gene expression in murine mammary epithelial stem cell-like cells shows similarities to human breast cancer gene expression
}

\author{
Cecilia Williams ${ }^{1,2}$, Luisa Helguero², Karin Edvardsson ${ }^{1,2}$, Lars-Arne Haldosén² and Jan- \\ Åke Gustafsson ${ }^{1,2}$
}

\author{
1Department of Biology and Biochemistry, Center for Nuclear Receptors and Cell Signaling, University of Houston, 3013 Science \& Engineering \\ Research Center, Houston, TX 77204, USA \\ 2Department of Biosciences and Nutrition, Novum, Karolinska Institutet, 14157 Stockholm, Sweden \\ Corresponding author: Cecilia Williams, ceciliawilliams@uh.edu
}

Received: 17 Dec 2008 Revisions requested: 10 Feb 2009 Revisions received: 8 Apr 2009 Accepted: 8 May 2009 Published: 8 May 2009

Breast Cancer Research 2009, 11:R26 (doi:10.1186/bcr2256)

This article is online at: http://breast-cancer-research.com/content/11/3/R26

(c) 2009 Williams et al.; licensee BioMed Central Ltd.

This is an open access article distributed under the terms of the Creative Commons Attribution License (http://creativecommons.org/licenses/by/2.0), which permits unrestricted use, distribution, and reproduction in any medium, provided the original work is properly cited.

\begin{abstract}
Introduction Mammary stem cells are bipotential and suggested to be the origin of breast cancer development, but are elusive and vaguely characterized. Breast tumors can be divided into subgroups, each one requiring specific treatment. To determine a possible association between mammary stem cells and breast cancer, a detailed characterization of the transcriptome in mammary stem cells is essential.
\end{abstract}

Methods We have used a murine mammary epithelial stem-like cell line $(\mathrm{HC} 11)$ and made a thorough investigation of global gene-expression changes during stepwise differentiation using dual-color comparative microarray technique. Subsequently, we have performed a cross-species comparison to reveal conserved gene expression between stem cells and subtypespecific and prognosis gene signatures, and correlated gene expression to in vivo mammary gland development.

Results Our analysis of mammary stem-like and stepwise cell differentiation, and an in-depth description of our findings in a breast cancer perspective provide a unique map of the transcriptomic changes and a number of novel mammary stem cell markers. We correlate the alterations to in vivo mammary gland differentiation, and describe novel changes in nuclear receptor gene expression. Interestingly, our comparisons show that specific subtypes of breast cancers with poor prognosis and metastasizing capabilities show resemblance to stem-like gene expression.

Conclusions The transcriptional characterization of these mammary stem-like cells and their differentiation-induced gene expression patterns is here made widely accessible and provides a basis for research on mammary stem-like cells. Our comparisons suggest that some tumors are more stem-like than others, with a corresponding worse prognosis. This information would, if established, be important for treatment decisions. We also suggest several marker candidates valuable to investigate further.

\section{Introduction}

The mammary gland exhibits unique developmental features during puberty, pregnancy and lactation. For each round of pregnancy, the mammary gland undergoes sequential cycles of proliferation, differentiation and apoptosis, and alveolar ducts form and grow, differentiate to produce milk and, after lactation, cease, revert and regress to the pre-pregnancy state. These and several other observations point towards the presence of stem cells as the basis for the capacity for alveolar renewal in each pregnancy (reviewed in [1]). These stem cells would be the origin of the epithelial compartment, where committed precursor cells become restricted to either a myoepithelial or luminal (ductal or alveolar) fate [1].

The cellular identity and markers of a rapidly cycling population of normal adult mammary stem cells have been suggested [2]. Some current models explain cancer development by the stem cell and clonal evolution hypothesis [3]. A bipotential mammary epithelial stem cell and/or a luminal progenitor cell would, via acquired genetic alterations, epigenetic changes and para- 
crine signals from surrounding cells, abandon its controlled stem cell self-renewal and develop into a breast tumor cell with uncontrolled growth $[3,4]$. Depending on the cell of origin (stem cell or progenitor cell) and acquired changes, different forms of breast cancer can develop. Tumors are further hypothesized to be sustained by the subpopulation of cancer stem cells [5], which should be specifically targeted for longterm successful therapeutic intervention.

The only factor known to consistently decrease lifetime breast cancer risk is early childbirth and breastfeeding [6]. This is speculated to be due to decreased circulating hormones, increased differentiation of the mammary cells and/or a decrease of mammary stem cells in the gland [7]. Exposure to estrogen is a risk factor for the development of breast cancer. The effects of estrogens are mediated via two estrogen receptor (ER) isoforms: ER $\alpha$ and ER $\beta$. Activation of ER $\alpha$ drives the proliferation in most of ER $\alpha$-positive breast tumors, whereas $\mathrm{ER} \beta$ can behave as an antagonist to ER $\alpha$ at the transcriptional level [8] and may be of protective value in breast cancer. Epidemiological studies also suggest that the breast is at particular risk to acquire deleterious genetic changes before or during puberty, which is thought to be a period of stem cell expansion. At this time, exposure to phytoestrogens, ligands of $\mathrm{ER} \beta$, has also been shown to be protective [9].

The overwhelming majority of breast cancers have luminal epithelial characteristics. Five molecular subgroups of breast cancer have been defined that can be distinguished according to their gene expression profiles: basal like, luminal A, luminal $C$, $\mathrm{Her}^{+}$and normal breast like [10]. Two nuclear receptors, $\mathrm{ER} \alpha$ and its downstream target the progesterone receptor, are two of the most important prognostic markers of breast cancer, whose expression is an indication that anti-estrogenic therapy can be successful. Most luminal $A$ and luminal $C$ tumors express these markers, but luminal $A$ tumors have a considerably better prognosis than luminal $C$ tumors. Most basal-like, normal breast-like and $\mathrm{Her}^{+}$subtypes do not express ER $\alpha$; of these subtypes, Her2 ${ }^{+}$and basal like have a worse prognosis [10]. There is a need for improved prognostic markers and tailor-made treatment for each of these groups.

The normal mammary epithelial cell line $\mathrm{HC} 11$ originates from mid-pregnancy BALB/c mice [11], and resembles mammary stem cells or progenitor cells remarkably. HC11 cells exhibit both self-renewal and ability for pluripotency: these cells can be cultured for an unlimited number of passages in a proliferating stem cell-like phase, they can be made to functionally differentiate and express milk proteins in vitro [11] and they can reconstitute the ductal epithelium of a cleared mammary fat pad with myoepithelial, alveolar and ductal luminal cells in vivo [12]. This cell line can be cultured without requirements for complex exogenously added, without extracellular matrix or without co-cultivation with other cell types for the prolactindependent in vitro induction of differentiation [11].
Few studies have been performed to investigate the underlying mechanisms when proliferating mammary epithelial cells differentiate using such pure cell systems of normal stem-like cells. Desrivières and colleagues have performed initial studies at the proteome level $[13,14]$ in the HC11 cells, and different mammary epithelial subpopulations (basal/myoepithelial, luminal $E R \alpha$-positive and luminal $E R \alpha$-negative) were recently characterized at the transcriptome level [15]; however, a broad description of mammary stem cell or stem cell-like transcriptomes and their change during differentiation is lacking. In vitro models have the benefit of representing homogeneous cell populations, giving enough material for thorough, repeated and high-quality analysis, allowing manipulations to better understand development, characteristics and responses and minimizing animal use.

In the present study, the undifferentiated stage of the $\mathrm{HC} 11$ cells is referred to as stem like, since the cells have the capability of both self-renewal and pluripotency, but it is not entirely clear whether the $\mathrm{HC} 11$ cells are complete stem cells or are in the process of becoming progenitor cells. In order to investigate the transcriptional events behind this stem cell-like state, to provide a map of mammary epithelial cell differentiation and to determine a possible connection between mammary stem cells and breast cancer, we have performed a complete analysis of all 36,000 known genes and transcripts using dualcolor microarray of the stem cell-like stage and different differentiation stages of these cells. We have compared this stem cell-like transcriptome with in vivo mammary gland development and with gene expression signatures of different types of human breast cancers and their metastases, and have analyzed the biological consequences in the context of stem cell and breast cancer interaction in detail. We report potential stem-like markers, and show their specificity at the protein level.

\section{Materials and methods Cell culture and induction of differentiation}

HC11 mammary epithelial cells were routinely grown in complete medium (RPMI 1640, 10\% FBS, L-glutamine, $5 \mu \mathrm{g} / \mathrm{ml}$ insulin, $10 \mathrm{ng} / \mathrm{ml}$ epidermal growth factor, and $50 \mu \mathrm{g} / \mathrm{ml}$ gentamicin; all from Sigma, St Louis, MO, USA), and proliferating cells were obtained under these growth conditions. When cells reached confluence, the complete medium was changed to medium without epidermal growth factor (RPMI 1640, $2 \%$ FBS, $5 \mu \mathrm{g} / \mathrm{ml}$ insulin, and $50 \mu \mathrm{g} / \mathrm{ml}$ gentamicin), and pre-differentiated (competent) cells were obtained after 48 hours of growth in this medium. To induce differentiation of competent cells, cultures were treated for 72 hours with medium without epidermal growth factor containing $100 \mathrm{nM}$ dexamethasone and $1 \mu \mathrm{g} / \mathrm{ml}$ ovine prolactin.

\section{Animals and mammary gland tissue}

Female Balb/c mice were fed ad libitum and were kept under a 12-hour light, 12-hour dark cycle. Mammary glands from 2- 
month old virgin, 10-day pregnant and 6-day lactation mice were excised and frozen in liquid nitrogen for RNA extraction. All animal experimentation was conducted in accordance with accepted standards of humane animal care as outlined by the Stockholm South Ethical Committee of the Swedish National Board for Laboratory Animals.

\section{RNA extraction}

RNA was extracted with TRIzol (Invitrogen, Carlsbad, CA, USA) according to standard protocol, and purified using Qiagen RNeasy spin columns (Qiagen, Hilden, Germany) with oncolumn DNase I digestion.

\section{Microarray experiment and analysis}

Raw data and detailed protocols for the microarray analysis are available from the ArrayExpress data repository [E-MEXP969]. In short, Operon's long-oligonucleotide spotted arrays covering the whole known genome represented by 36,000 genes and gene transcripts were used (printed by the microarray facility at KTH, Royal Institute of Technology, Stockholm, Sweden). Triplicate cultures of stem-like, pre-differentiated and differentiated stages of $\mathrm{HC} 11$ were analyzed in 10 hybridizations using $20 \mu \mathrm{g}$ total RNA per sample (20 samples); each microarray comparison was replicated and dye-swapped with different sets of cultures to compensate for unequal dye incorporation and variance between cultures and differentiations. Hybridizations were performed in a loop design, where stemlike stage was hybridized to pre-differentiated stage, pre-differentiated stage to fully differentiated stage and, in addition, stem-like stage to fully differentiated stage. Scanning was carried out at $10 \mu \mathrm{m}$ resolution using the G2565BA DNA microarray scanner (Agilent Technologies, Santa Clara, CA, USA), for which the photomultiplier tube was set to 100 .

The obtained TIFF images were analyzed using the GenePix Pro 6 software (Molecular Devices Corp., Union City, CA, USA), in which TIFF files generated for Cy3 channels and Cy5 channels were superimposed upon each other. Spot identification, manual examination of the surface of the array and flagging of spots/regions with poor quality were performed in GenePix. Result files (gpr files) produced by GenePix were imported into the $\mathrm{R}$ environment for statistical computing and programming, where data processing and identification of differentially expressed genes were carried out using the Bioconductor package bundle, Limma, aroma package and the kthpackage. Unreliable spots with abnormal physical properties were removed using several filters. After filtering, the slides were normalized with print-tip loess (local regression) normalization. To identify differentially expressed genes, a parametric empirical Bayes approach implemented in Limma was used [16]. This test statistic will assign a score (B-score) to each gene. The B-score was used to rank the genes so that the gene with the highest score has the highest probability of being differentially expressed. When differences were being investigated, two criteria had to be fulfilled for a gene to be regarded as differentially expressed: the gene had to have a Bscore of more than 0 and an |M-value| of more than 0.5 (an Mvalue is the second logarithm of the fold change).

Genes close to cut-off $(\mathrm{B}>0.0,|2 \log \mathrm{FC}|>0.4$ and $P<$ 0.005 ) could be confirmed by real-time PCR in three independent differentiation cultures. Confirmations of 22 genes were performed.

\section{Over-representation analysis}

Analysis of over-represented themes and classification into gene ontology functional groups was performed using Expression Analysis Systematic Explorer [17]. The complete mouse transcriptome was used to calculate expected frequencies of over-represented themes. Gene ontology groups were considered over-represented when the calculated Expression Analysis Systematic Explorer score (modified Fischer Exact probability test) was $\leq 0.2$.

\section{Real-time PCR}

cDNA was synthesized with Superscript III (Invitrogen) and random hexamers using $1 \mu \mathrm{g}$ DNase-l-treated and purified RNA. Real-time PCR was performed with SYBR-Green Mastermix (Applied Biosystems) according to the manufacturer's protocol, using $10 \mathrm{ng}$ cDNA per $10 \mu \mathrm{l}$ reaction in an $\mathrm{ABI}$ PRISM 7500 (Applied Biosystems, Foster City, CA, USA) under the following conditions: $95^{\circ} \mathrm{C}$ for 10 minutes, followed by 40 cycles at $95^{\circ} \mathrm{C}$ for 15 seconds and $60^{\circ} \mathrm{C}$ for 40 seconds. All runs were performed in triplicate from triplicate cultures, and specific amplification was checked with melting curve analysis. Primer sequences of intron-spanning fragments will be provided on request. The $\Delta \mathrm{Ct}$ formula was used to determine fold-change differences, and $18 \mathrm{~S}$ was used as the reference gene.

\section{Western blot}

$\mathrm{HC} 11$ cells were grown in $10 \mathrm{~cm}$ plates and were differentiated as described above. Cells were washed with PBS, collected in a $1.5 \mathrm{ml}$ tube, and pelleted by centrifugation at $4^{\circ} \mathrm{C}$ for 2 minutes. The cell pellets underwent one cycle of freezethaw and were resuspended in lysis buffer (1\% NP-40, $50 \mathrm{mM}$ Tris- $\mathrm{HCl}, \mathrm{pH} 7.5,140 \mathrm{mM} \mathrm{NaCl}, 2 \mathrm{mM}$ ethylenediamine tetraacetic acid, $1 \mathrm{mM}$ phenylmethanesulphonylfluoride, $1 \mathrm{mM}$ $\mathrm{Na}_{3} \mathrm{VO}_{4}$ and protease inhibitor cocktail; Roche, Mannheim, Germany). The lysate was kept on ice for 20 minutes and was centrifuged at $14,000 \mathrm{rpm}$ for 10 minutes at $4^{\circ} \mathrm{C}$. The protein concentration was determined with Bradford reagent (BioRad, Hercules, CA, USA). Whole-cell extracts ( $40 \mu \mathrm{g}$ protein) were resolved on SDS-PAGE and transferred onto a Polyvinylidene Fluoride membrane.

The membranes were blocked with $5 \%(\mathrm{w} / \mathrm{v})$ milk protein dissolved in PBS and were incubated overnight at $4^{\circ} \mathrm{C}$ with the following primary antibodies: rabbit anti-ADAMTS1 (GTX11557; Genetex, Irvine, CA, USA), chicken anti-DUSP6 
(GTX19115; Genetex), rabbit anti-Birc5 (also known as survivin, \#2808; Cell Signaling, Houston, TX, USA), rabbit antiMelk (\#2274; Cell Signaling), and mouse anti-COUP TF2 (ab41859; AbCam, Cambridge, UK) and rabbit anti-tubulin (\#2125; Cell Signaling) was used as loading control. The antibodies were considered specific based on previous data and detection of few bands in the blots, and in all cases the molecular weight of the corresponding bands was calculated using Quantity One software (BioRad). The secondary antibodies were coupled to horseradish peroxidase (Sigma). The luminescent signal was detected with the enhanced chemiluminescence kit (Amersham, Buckinghamshire, UK).

\section{Immunocytochemistry and immunohistochemistry}

HC11 cells were cultured on eight-well glass chamber slides (BD Biosciences, Meylan Cedex, France). Cells were fixed in $10 \%$ buffered formalin and permeabilized in $0.5 \%$ Triton-PBS for 30 minutes. Unspecific binding was blocked by incubation in blocking solution for 1 hour (10\% FBS in 0.1\% TweenPBS). Incubation with the primary antibodies proceeded overnight at room temperature. The primary antibodies used were the same as for western blots and also anti-mouse CD44 (\#553991; BD Pharmigen, San Diego, CA, USA), mouse antikeratin 5/8 (MA1-35858; Affinity Bioreagents, Rockford, IL, USA) and mouse anti-Rab4 (ab13252; AbCam). After three washes with PBS, the corresponding secondary antibodies anti-mouse-Cy3 (Sigma), anti-rabbit or anti-chicken Alexa 488 (Molecular Probes, Invitrogen, Eugene, OR, USA) and antimouse Alexa 568 (Molecular Probes) - were added (1/500 in blocking solution) for 1 hour. Cells were washed four times with PBS and nuclei were stained with ToPro-3 (1/1,000; Molecular Probes). To assess whether the staining was due to binding of the primary antibody, a group of samples was stained in parallel but only with the secondary antibody. Images were captured using a laser-scanning confocal microscope (Zeiss 510, Stockholm, Sweden). Images were acquired under the same settings; when edited with Adobe Photoshop 6.0, the same adjustments were applied to all images.

\section{Results and discussion Mammary stem-like cell transcriptome}

To explore the largely unknown transcriptome of mammary stem cells we compared the murine mammary stem-like cells with their pre-differentiated and fully differentiated stage. In this way, all changes of genes and important networks for commitment of cell fate, implementation of differentiation programs, specification and survival were revealed. The most highly changed genes, at stem cell-like exit, are presented in Tables 1 and 2, gene enrichment analysis of over-represented and under-represented processes is listed in Table 3, and a schematic overview of changed processes is depicted in Figure 1. All regulated genes are available in Additional file 1, and real-time confirmations of 22 genes are available as Additional files 2 to 4 . Confirmations at the protein level are depicted in Figures 2 to 5 .

Our analysis confirmed previous findings, including: an increase of Stat1 and Stat5a during differentiation, which also mimics the in vivo control of proliferation, differentiation and survival during mammary gland differentiation [18]; an increase of Ctgf expressed, also found in the in vivo mouse mammary gland during pregnancy and lactation [19]; an increase of Lamp1, a differentiation marker for HC11 [20]; and an increase of Igfbp5, whose expression is stimulated during cellular differentiation by lactogenic hormones [21]. Further, a decrease of Igfbp2 [21], Hnrpd [22], Cyclin D 1 and Myc [23] during the differentiation of these cells was confirmed. In addition to the above verifications, which in themselves demonstrate a high reproducibility of the differentiation process and of the analysis, a total of 2,251 genes was observed to be changed in the first step of commitment to differentiation, and a further 1,010 alterations during the subsequent stage of functional differentiation. The majority of these alterations are novel, and the implications of many of them are at this time unknown.

When cells left the stem-like stage and entered the pre-differentiation stage, gene enrichment analysis of processes - as defined by the Gene Ontology Consortium - showed that differentiation (particularly epithelial differentiation), skeletal development, cell adhesion, regulation of apoptosis and several types of metabolisms (coenzyme, lipid, carbohydrate, oxygen and sulfur metabolism) increased (Figure 1, box A). At the same time, there was a robust decrease in expression of mitotic cell cycle-associated genes, metabolism of DNA, RNA, nucleotide and proteins, respectively, and angiogenesis (Figure 1, box B). Most genes that were altered in the first transition remained at this level in the second transition, such as upregulated genes within vesicle-mediated transport, cell adhesion and epithelial cell differentiation (Figure 1, box $\mathrm{G}$ ). Expression of other genes continued to increase: for example, skeletal development and positive regulation of transcription (Figure 1, box E). There was also a significant increase of protein modifications and additional cell adhesion gene expression specific for the second transition (Figure 1, box F). The strong slow-down of proliferation in the first differentiation transition partially continued in the second differentiation step (Figure 1, box J - also signified by a strong decrease in proliferation marker Mki67), whereas most of the decreased cell cycle genes did not change further in the second transition (Figure 1, box H). Organelle organization, biogenesis, organogenesis and regulation of proteolysis and peptidolysis started to decrease in the second transition (Figure 1, box I). A temporary increase of 58 genes, pronounced within programmed cell death genes (Figure 1, box C), and a temporary decrease of protein metabolism genes (Figure 1, box D) were specific changes that only occurred in the pre-differentiated stage. 


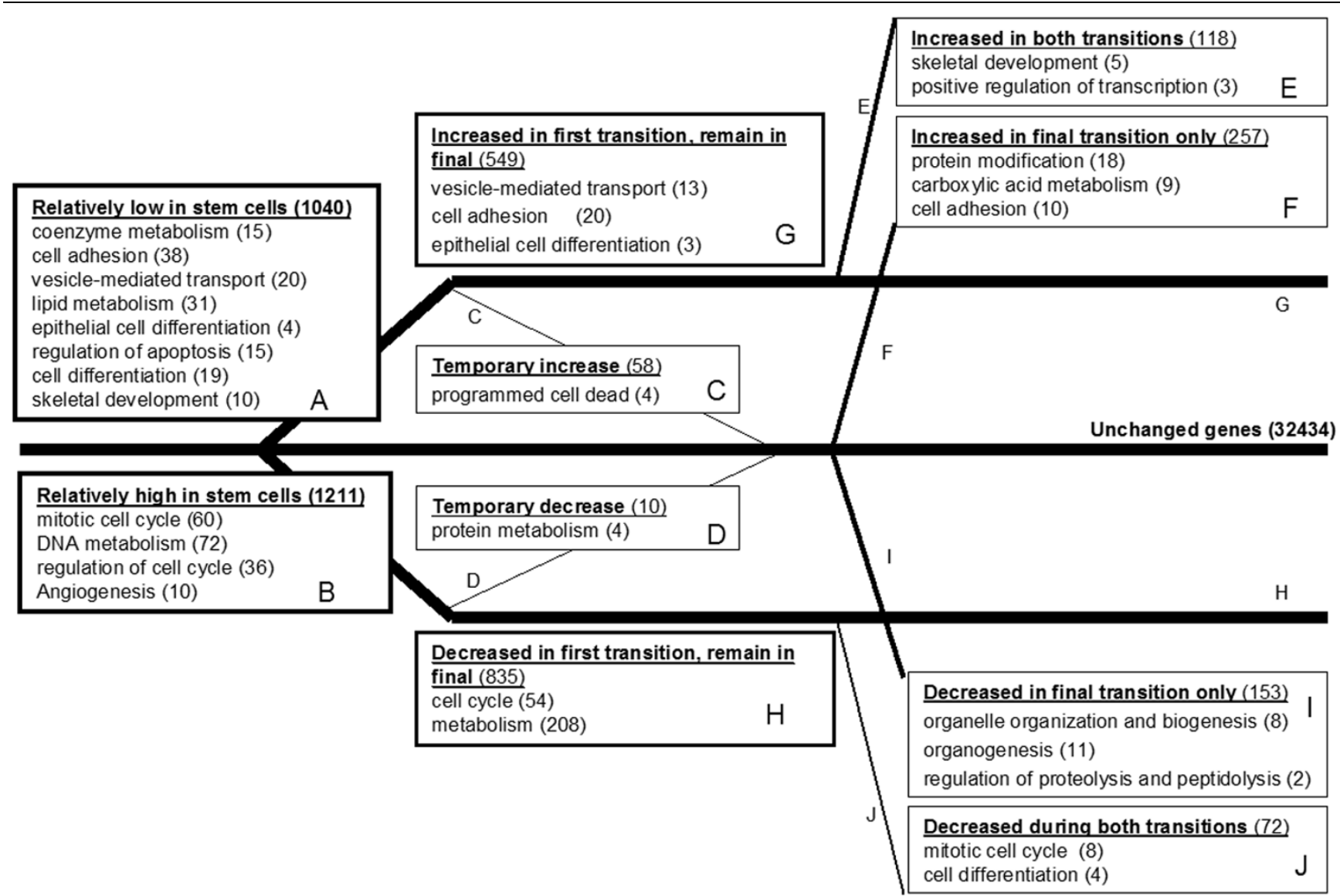

\section{Stem cell-like $\longrightarrow$ Pre-differentiated $\longrightarrow$ Fully differentiated}

Schematic overview of mammary stem cell-like cells to differentiation transcriptome transition. Gene categories (as defined by the Gene Ontology Consortium) over-represented among differentially expressed genes during the transition from stem-like mammary epithelial cells via pre-differentiated cells to fully differentiated cells. Over-representation analysis was performed using Expression Analysis Systematic Explorer (EASE) software, with an EASE score (a conservative adjustment of Fisher's exact probability to weigh significance in favor of gene ontology categories supported by many genes) cut-off below 0.02. Boxes $A$ and $B$ denote overall changes between the first and second transitions (stem cell-like stage compared with pre-differentiated stage). Boxes $\mathrm{C}$ to $\mathrm{J}$ denote subgroups where a changed or unchanged value is acquired in the microarray analysis for both transitions (stem cell-like stage compared with pre-differentiated stage, as well as pre-differentiated stage compared with fully differentiated stage). Number of genes within each group and process are shown within parentheses.

Among the most strongly altered genes (Tables 1 and 2), transcript levels of amino acid phosphorylation proteins (including Melk) and dephosphorylation proteins (including Dusp6) were highly elevated at the stem-like cell stage and decreased considerably during differentiation. Melk and Dusp6 expression was further corroborated at the protein level (Figure $2 a, b$ ), where the decrease upon differentiation was evident. A large group of different histone transcripts were also found to be strongly downregulated during differentiation - for example, Hist1h1a confirmed by real-time PCR (Additional file 2), Hist1h4h, Hist1h3c and H2afz (Table 1). When differentiation starts, gene expression of proteinase inhibitor activity (Expi, confirmed by real-time PCR; Additional file 2), proteolysis proteins (such as cathepsin D and cathepsin A) and transcriptionrelated proteins (Ehf, confirmed by real-time PCR (Additional file 2), Plagl1, Stat1, Stat3, Stat5a and Stat6) increased. From these data we can conclude that the HC11 stem-like cells have a high activity of cell cycle, protein phosphorylation and angiogenic activities coupled with low adhesion, apoptosis, transcriptional activity and differentiation.

\section{Mammary stem cell characteristics in the HC11 stem-like cells}

The exact features of mammary stem cells are not fully known, and there are disagreeing reports of mammary stem cell characteristics. Also the exact stem cell characteristics of the cell line used here are unspecified, but exhibit several trademarks of stem cells. The HC11 cells are immortal and have the capability of self-renewal and pluripotency, and maintain properties that allow them to differentiate in vitro in response to lac- 

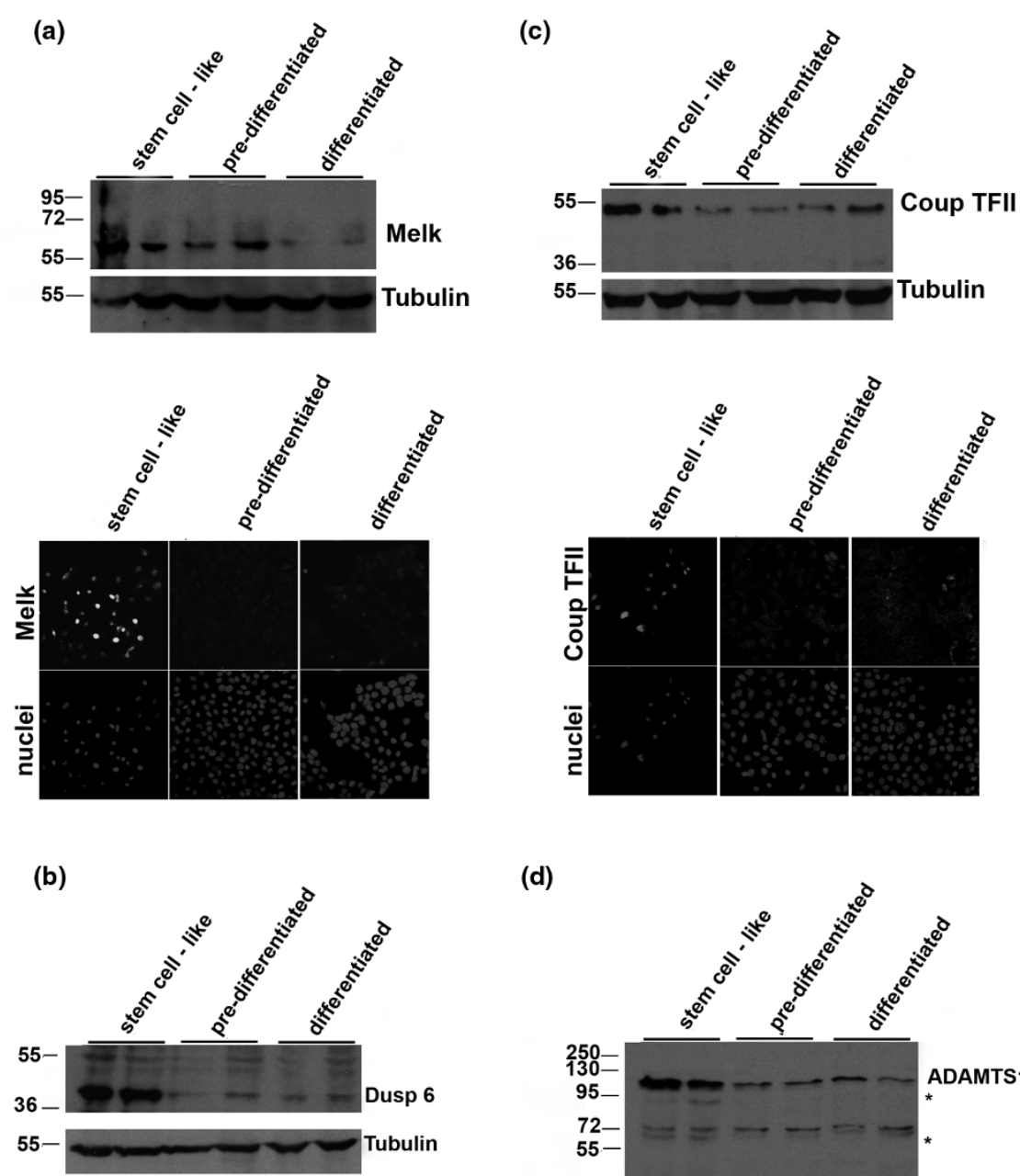

(d)

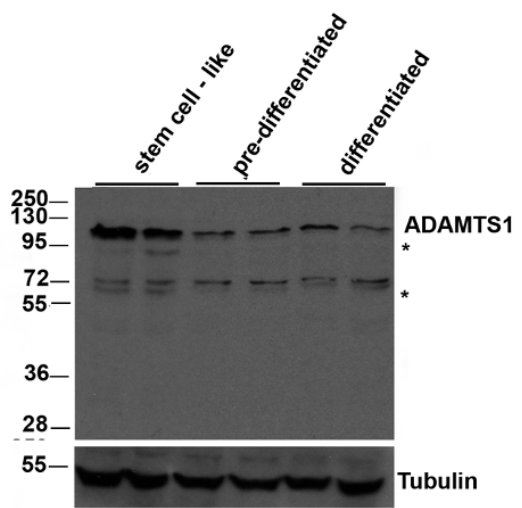

Protein expression in $\mathrm{HC} 11$ stem-like, pre-differentiated and differentiated cells. (a) Melk expression analyzed by western blot and immunofluorescence. (b) Dusp 6 expression by western blot. (c) COUPTF-Il expression by western blot and immunofluorescence. (d) ADAMTS1 expression analyzed by western blot. *Processed forms of the zymogen. In all cases, whole cell extracts were resolved on 10\% SDS-PAGE and membranes blotted with the indicated antibodies. Tubulin was used as loading control.

togenic hormones. Their repopulation potential in vivo may not be perfectly reproducible, however, and the expression of stem cell markers is not well established. Further, these cells are proliferating, which our current dogma suggests stem cells of the mammary gland are not. These cells may be in the process of becoming progenitor cells, or they may possibly constitute a mixture of stem and progenitor cells. Regardless, it is of great interest to define the potential stem-like gene expression pattern and/or markers for these cells.

To evaluate our material for stem cell characteristics, we compared the gene expression of the stem-like stage with findings reported or suggested by others. A bipotential human stem cell is hypothesized to be $\mathrm{Cd}_{4} 4^{+}$[3], an adhesion molecule with roles in signaling, migration and homing. We found that Cd44 was highly expressed at the stem-like cell stage and decreased extensively during differentiation at the mRNA level. Cd44 at the protein level also decreased with differentiation (Figure 3a), although occasional cells remained positive also in the differentiated stage. Furthermore, a receptor with similar properties to $\mathrm{Cd} 44, \mathrm{Hmmr}$, was strongly overexpressed in the stem-like stage. A strong correlation with other suggested mammary stem cell marker genes was observed; that is, Brca1 [24], Krt6, Krt5 [25] and Melk, a suggested stem cell gene in 
Figure 3
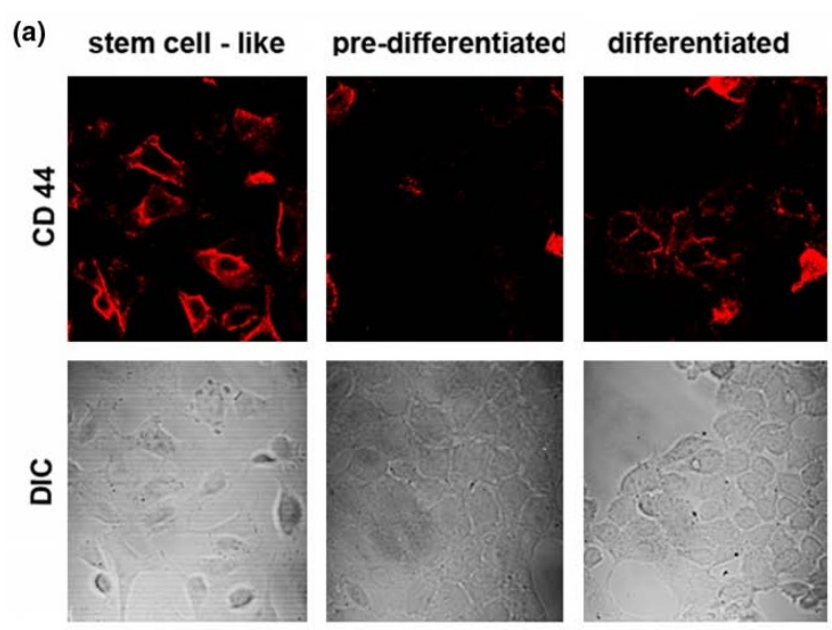

(b)

stem cell - like
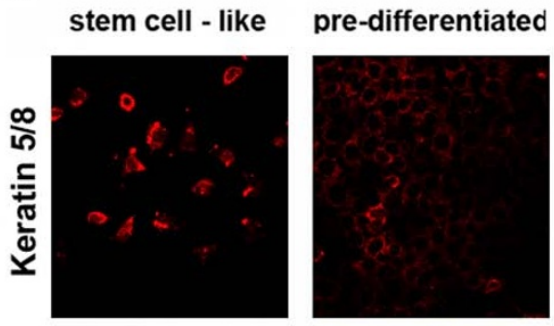

\section{differentiated}
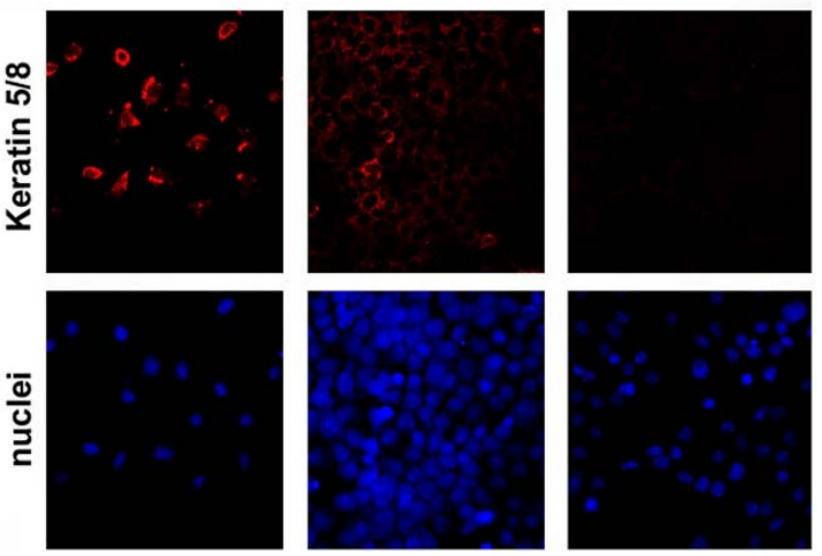

Expression of stem cell markers in HC11 mammary epithelial cells. (a) CD44 expression. DIC, differential interference contrast allows visualization of the cells. Note that the proportion of CD44-positive cells decreases as the culture differentiates but the intensity of the signal in those cells that are positive remains constant. (b) Keratin 5 and Keratin 8 (Krt 5/8) expression.

hematopoietic [26], neural [27] and possibly epidermal stem cells - the latter two genes were observed and corroborated also at protein level (Figure $3 \mathrm{~b}$ and Figure 2a, respectively).

A novel mechanism for the control of stem cell proliferation in embryonic and neural stem cells involving histone H2afx was recently described [28]. We found this gene to be overexpressed in our stem-like cells. This histone gene has also been shown to exhibit copy number changes in sporadic breast cancer [29]. Vim (vimentin), a suggested stem cell marker in mesenchymal cells [30], also showed a decrease during differentiation (corroborated at protein level; Additional file 6). Other possible stem cell markers, however, showed an opposite expression in these cells: Lrp5 (a reported cell surface marker for somatic mammary stem cells), Musashi homolog 2
(Msi2, a neuronal stem cell marker) and both Kit and Kitl (stem cell markers in hematopoietic stem cells) were all upregulated at the transcript level during differentiation of $\mathrm{HC} 11$ mammary stem cell-like cells.

Murine mammary stem cells have further been selected using protein markers CD45/Ptprc-' Ter119/Ly76-, CD31/Pecam1; Sca-1/Ly6alow, CD24/Cd24amed and CD49f/ltga6high by Stingl and coworkers [2]. In our HC11 material, however, these markers were not significantly changed at the transcript level. One reason for these apparent differences may be that the protein levels at the cell surface do not always follow the mRNA levels, so even if the transcript for a specific gene does not change, other mechanisms can affect both protein localization and stability. Another reason could be related to where in the process between pure stem cells towards progenitor cells our stem-like cells and/or the literature reported cells are residing. The transcription factor Etv4 (Pea3), suggested to function in multipotential mammary progenitors to regulate their lineage-specific differentiation potential by Kurpios and colleagues [31], was at the highest expression in the stem-like stage.

HC11 cells have the capacity to differentiate in vivo into both myoepithelial and luminal (ductal and alveolar) epithelial cells. Both markers of myoepithelial lineage (Mme/Cd10) and luminal epithelial lineage (Krt18) increased strongly during differentiation. Further, we compared the expression patterns of the HC11 cell differentiation stages with the three different mammary epithelial cell subpopulations - basal/myoepithelial, luminal ER $\alpha$-positive and luminal ER $\alpha$-negative - from virgin mouse mammary gland, characterized at the transcriptome level in a study by Kendrick and colleagues [15]. Genes specific for each of the three subgroups were increasing in expression during differentiation of the HC11 cells, further proving that all lineages are represented in the differentiated stage. We found that whereas nearly all luminal specific genes that were changed during the differentiation of $\mathrm{HC} 11$ cells were upregulated (79 out of 82 for luminal ER-positive and 79 out of $\mathbf{8 4}$ for luminal ER-negative), about one-half of the genes specific for basal/myoepithelial lineage (99 genes) were upregulated during differentiation, whereas the remaining 91 genes decreased. The reason for this could be that, because the basal cell layer also contains the mammary epithelial stem cell compartment [32], and genes in the stem cells should be downregulated during differentiation, genes in differentiated cells in the basal/myoepithelial lineage should be correspondingly upregulated during differentiation. The luminal cells should be mostly represented by differentiated cells, and genes in these cells would be expected to be upregulated during $\mathrm{HC} 11$ differentiation.

During midgestational mammary development in vivo, several signal transducers and activators of transcription are known to be increased by prolactin; in the $\mathrm{HC} 11$ cells, Stat 1 (Table 2), 

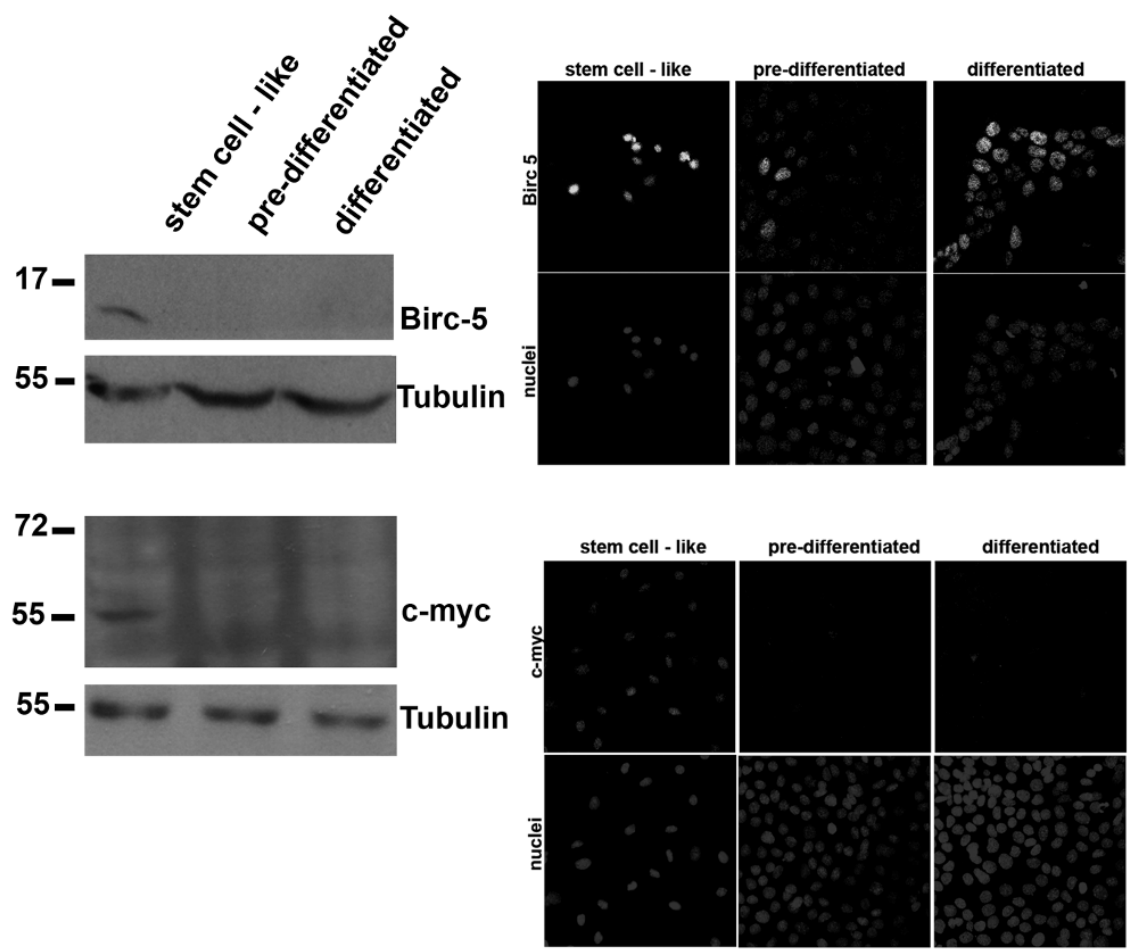

Expression of Wnt regulated genes in $\mathrm{HC} 11$ stem cell-like, pre-differentiated and differentiated cells. Wnt regulated gene expression evaluated by western blot and immunofluorescence in $\mathrm{HC} 11$ stem cell-like cells, pre-differentiated cells and differentiated cells. Top panel, Birc5; bottom panel, cmyc. In all cases, whole cell extracts were resolved on $12 \%$ SDS-PAGE and membranes were blotted with the indicated antibodies. Tubulin was used as loading control.

Stat3, Stat5a and Stat6 as well as the prolactin-induced protein increased, indicating that the cells retain this mammary epithelial cell-differentiation attribute. Furthermore, the milk protein $\beta$-casein was expressed in differentiated cells (Additional file 7).

Activity of the Wnt, Hedgehog and Notch pathways are other hallmarks of stem cell characteristics. In the HC11 cells, drastic changes of expression of Wnt members during differentiation was not observed; however, several known positively regulated Wnt target genes [33] were strongly downregulated during differentiation (Ccnd1, Birc5, Cd44 and Myc, all corroborated at mRNA and/or protein level (Figures 3 and 4, Additional file 2), and Cyr61, Fosl1, Cd87/Plaur, Met, Fst, Emp1, Abcb1b, Ptgs2, Abcb1b, Runx2, Gja1, IL6, Mycbp), and targets known to be downregulated by Wnt were correspondingly upregulated (Cdh1, confirmed at mRNA level (Additional file 2), Sox9 and Postn), in agreement with a higher Wnt activity at the stem-like cell stage. This normal downregulation of the Wnt pathway during differentiation correlates to a previous report by Shackleton and colleagues showing that normal differentiation could be inhibited by the over activation of the Wnt pathway [32]. Several members of the Hedgehog pathway (including Snail and Prkca) and the Notch pathway (including Jag1, Jag2, Hr, Lfng, Hes1) were also changed during differentiation.

A large study of heterogeneous collections of gene expression data generated from 83 mouse stem cell-related samples defined four super-families of stem cell markers associated with differentiation: serine proteinase inhibitors (serpins), cytochrome P450 family, Rab family GTPases, and nuclear receptors [30]. In HC11 mammary cells, differentially expressed genes signified all of these four groups. Two serpins (Serpine1 and Serpine2) were highly reduced as the stem-like cells underwent differentiation. Serpine 1 is also involved in regulation of angiogenesis in breast cancer, and Serpine 2 in cell differentiation. In a previous study of differentiating hematopoietic stem cells we also identified two serpins as strongly reduced (Serpin a3g and a3n) [34], of which expression of Serpina $\mathrm{g}$ has been shown to prevent stem cells from differentiation [35]. We further found an increase of Group 2 genes (two cytochrome P450 members, Cyp2f2 and Cyp4x1, in the HC11 cells) and several Rab family GTPases in Group 3 (increase of Rab4a (confirmed at protein level in Figure 5), Rab1, Rab3a, Rab5b, Rab15, Rab18, Rab25, and related 

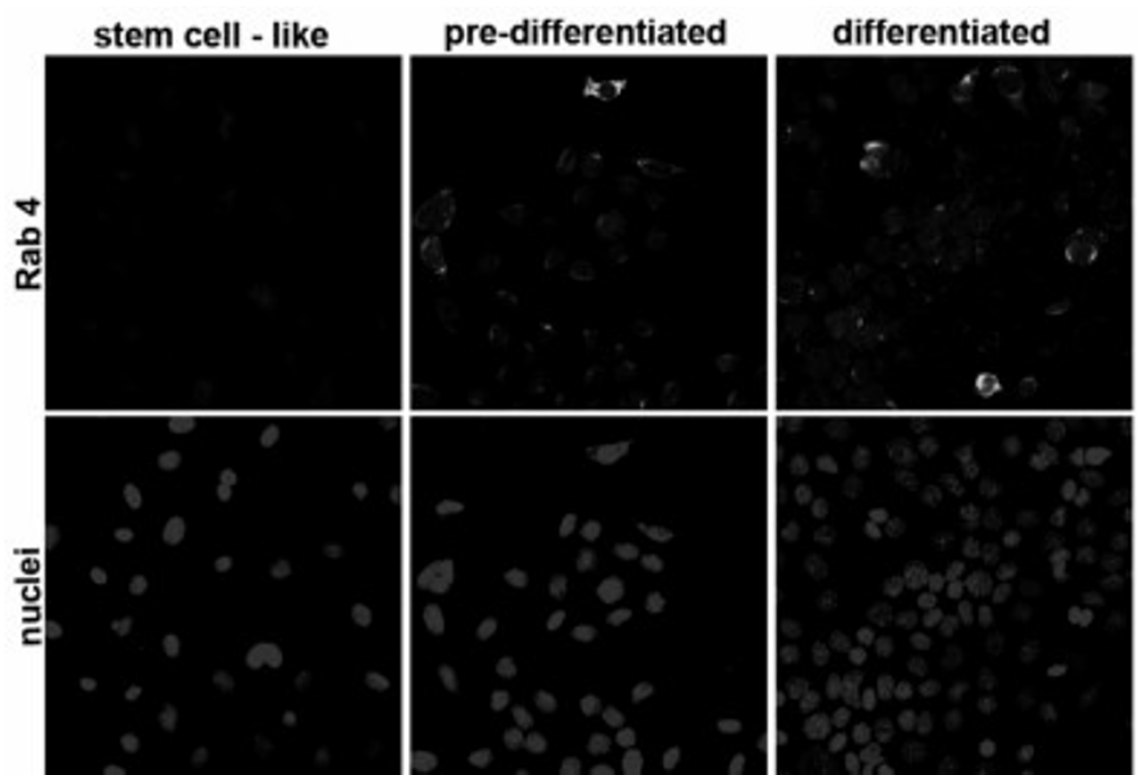

Rab4 expression in HC11 stem-like, pre-differentiated and differentiated cells. Rab4 expression analyzed by immunofluorescence in HC11 stem-like cells, pre-differentiated cells and differentiated cells.

gene family members Rhoj, Rhoq, Rhou; and decrease of two Rab family GTPases Rab12 and Rab32) as the mammary stem-like cells differentiated.

Group 4 (nuclear receptors) was also differentially expressed in HC11 mammary stem-like cells. Ten nuclear receptors changed their expression when the mammary stem-like cells differentiated. COUP-TFII, COUP-TFI, FXR $\beta$, NGFIB, NURR1 and ER $\beta$ decreased (Additional file 5). COUP-TFII and COUPTFI influence proliferation of breast cancer cells $[36,37]$ and are implicated in metastasis [38]. In the fly the common ancestral gene (svp/NR2F3) regulates stem cell identity of neuroblasts [39]. Figure 2c clearly shows the downregulation of COUP-TFII also at the protein level when the cells start differentiating. Further, ROR $\alpha$, VDR, EAR2 and ER $\alpha$ increased (Additional file 4). ROR $\alpha$ is frequently inactivated in breast cancers, and VDR is indicated to be protective against breast cancer [40]. Both COUP-TFIl and ROR $\alpha$ are among 426 selected markers of stem cells described [30]. Further, we noted that both ER $\alpha$ and $\mathrm{ER} \beta$ were among the nuclear receptors that changed during differentiation. Both are involved, in opposing manners, in mammary development and breast cancer [8].

Taken together, a number of stem cell-related changes as well as changes indicative of a mixture of both myoepithelial and luminal cell fates are in line with the stem cell characteristics of these cells.

\section{Mammary stem-like cells show resemblance with breast cancer signatures}

To investigate whether there are similarities between human breast cancer gene expression and the stem cell-like expression of the murine $\mathrm{HC} 11$ cells, supporting the hypothesis that breast cancer primarily arises from mammary stem/progenitor cells [41], we compared our material of mammary stem-like gene expression with gene-profiling signatures of breast tumors. These profiles have a prognostic value equal to or better than clinicopathologic variables [42], and a 70-gene signature is able to distinguish sporadic breast cancer tumors with poor prognosis from those with favorable prognosis [43]. Comparison showed that the poor prognosis signature overlapped with the expression profile of the mammary stem celllike genes. In contrast, none of the genes indicating favorable prognosis were differentially expressed in the stem-like cells (Table 4).

Among signatures distinguishing subclasses of breast carcinomas [10], our stem-like signature showed an irrelevant overlap with subclasses nominated as normal breast like, as luminal epithelial containing ER, and as Her2+ ${ }^{+}$. For subtype luminal $\mathrm{C}$ and basal-like tumors, however, there was a considerable overlap of genes $(75 \%$ and $60 \%$, respectively; see Table 5). Patients with these two subclasses of breast tumors also show among the lowest survival [10]. The basal-like phenotype has been suggested to resemble normal mammary stem cells $[1,44]$, which is here demonstrated at the gene expression level. Both the HC11 cells and the poor-prognosis and basal-like tumors are characterized by high proliferation; nonetheless, many of the shared gene signatures are not 
Breast Cancer Research Vol 11 No 3 Williams et al.

Table 1

\section{Mammary stem-like specific gene expression}

\begin{tabular}{|c|c|c|c|}
\hline Symbol & Gene & $2 \log F C$ & Gene ontology \\
\hline Hist1h2bp & Histone 1, H2bp & -2.78 & Nucleosome assembly \\
\hline Hist1h2bk & Histone 1, $\mathrm{H} 2 \mathrm{bj}$ & -2.95 & Nucleosome assembly \\
\hline $\mathrm{Hmmr}$ & Hyaluronan-mediated motility receptor & -2.85 & Not defined \\
\hline Melk & Maternal embryonic leucine zipper kinase & -2.68 & Protein amino acid phosphorylation \\
\hline Cbln4 & Cerebellin 4 precursor protein & -2.38 & Not defined \\
\hline Hist2h2ac & Histone 2, H2ac & -2.55 & Nucleosome assembly \\
\hline Ccna2 & Cyclin A2 & -3.21 & Regulation of cell cycle \\
\hline Hist2h3c1 & Histone $2, \mathrm{H} 3 \mathrm{c} 1$ & -2.91 & Nucleosome assembly \\
\hline Birc5 & Baculoviral IAP repeat-containing 5 & -2.55 & Anti-apoptosis/embryonic development \\
\hline Exosc6 & Exosome component 6 & -2.10 & rRNA processing \\
\hline Tmpo & Thymopoietin & -1.60 & Regulation of transcription \\
\hline Hist1h4h & Histone $1, \mathrm{H} 4 \mathrm{~h}$ & -1.99 & Nucleosome assembly \\
\hline Lig1 & Ligase I, DNA, ATP-dependent & -1.97 & Cell cycle \\
\hline Dusp6 & Dual-specificity phosphatase 6 & -2.80 & Protein amino acid dephosphorylation \\
\hline Hist1h3c & Histone1, $\mathrm{H} 3 \mathrm{c}$ & -2.62 & Nucleosome assembly \\
\hline Ckap2 & Cytoskeleton-associated protein 2 & -1.97 & Cell cycle/apoptosis \\
\hline Adamts 1 & $\begin{array}{l}\text { A disintegrin-like and metalloprotease with thrombospondin type } \\
1 \text { motif, } 1\end{array}$ & -2.47 & Integrin-mediated signaling pathway/proteolysis \\
\hline Hist1h4a & Histone $1, \mathrm{H} 4 \mathrm{a}$ & -2.23 & Nucleosome assembly \\
\hline Mki67 & Antigen identified by monoclonal antibody Ki67 & -2.00 & Cell proliferation \\
\hline $\mathrm{H} 2 \mathrm{afz}$ & $\mathrm{H} 2 \mathrm{~A}$ histone family, member $\mathrm{Z}$ & -2.53 & $\begin{array}{l}\text { Nucleosome assembly/multicellular organismal } \\
\text { development }\end{array}$ \\
\hline Cyr61 & Cysteine-rich protein 61 & -2.89 & Regulation of cell growth/cell adhesion \\
\hline Rrm1 & Ribonucleotide reductase $\mathrm{M} 1$ & -2.44 & DNA replication \\
\hline Hist1h2ag & Histone 1, H2ag & -2.96 & Nucleosome assembly \\
\hline Lyar & Ly1 antibody reactive clone & -1.81 & Not defined \\
\hline Ube2c & Ubiquitin-conjugating enzyme E2C & -1.89 & Positive regulation of cell proliferation \\
\hline
\end{tabular}

Genes highly expressed at the stem-like stage, to decrease upon differentiation. Genes are listed in the order of statistical significance for being differentially expressed. 2 logFC denotes the 2 log of fold-change (a value of -2 equals a fourfold downregulation or a decrease by $75 \%$ upon differentiation).

directly linked to proliferation but to adhesion (for example, Tnc, Ly6e, Cdh3), protein phosphorylation (Melk), transcription (Id1), development (Ext1) and signal transduction (Ect2, Gpr126) (Tables 4 to 6).

Our results are in line with the recent report of poorly differentiated aggressive human tumors showing an embryonic stem cell-like gene expression signature [45]. Here a core set of nine embryonic transcription regulators was found to be overexpressed at the mRNA level in many poorly differentiated tumors, and in the HC11 cells we observed four of these tran- scription factors to be overexpressed at the stem-like cell stage (Mybl2, Hmga1, Hmgb3, Tead4). In conclusion, the comparisons presented here show that breast cancer subtypes defined by, for example, Sorlie and colleagues [10] can be further subdivided according to stem cell-like resemblance, and comparison with both the 70-gene signature, and Sorlie's classification reveals that stem cell-like expression infers worse prognosis. We speculate that subtypes with a higher degree of stem cell-like gene expression may have a higher fraction of cancer stem cells, yielding a more aggressive cancer. Specific markers to determine whether a tumor is stem 
Table 2

\begin{tabular}{|c|c|c|c|}
\hline Symbol & Gene & $2 \log F C$ & Gene ontology \\
\hline Expi & Extracellular proteinase inhibitor & 5.01 & Protease inhibitor activity \\
\hline Gas6 & Growth arrest specific 6 & 3.14 & Regulation of cell growth \\
\hline Slc6a6 & Solute carrier family 6 , member 6 & 2.88 & Neurotransmitter transport \\
\hline Ehf & Ets homologous factor & 3.66 & Transcription factor activity \\
\hline Ctsd & Cathepsin D & 2.88 & Proteolysis \\
\hline Xdh & Xanthine dehydrogenase & 1.83 & Lactation/regulation of epithelial cell differentiation \\
\hline $\mathrm{DOH} 4 \mathrm{~S} 114$ & Dna segment, human D4S114 & 3.32 & Regulation of Tgf-b signaling pathway \\
\hline Nupr1 & Nuclear protein 1 & 1.92 & Not defined \\
\hline $\mathrm{H} 2-\mathrm{T} 23$ & Histocompatibility $2, T$ region locus 23 & 1.75 & Antigen processing and presentation \\
\hline Atp6v0d1 & ATPase, $\mathrm{H}$ transporting, $\mathrm{V}_{0}$ subunit $\mathrm{D}$ isoform 1 & 1.78 & Proton transport \\
\hline Cd81 & CD 81 antigen & 2.03 & Positive regulation of cell growth \\
\hline D12Ertd647e & $\begin{array}{l}\text { DNA segment, Chr 12, ERATO Doi 647, expressed, transcript } \\
\text { variant } 3\end{array}$ & 2.22 & Not defined \\
\hline Cbr2 & Carbonyl reductase 2 & 2.92 & Metabolic process \\
\hline Plagl1 & Pleiomorphic adenoma gene-like 1 & 2.43 & $\begin{array}{l}\text { Positive regulation of transcription from RNA } \\
\text { polymerase II promoter }\end{array}$ \\
\hline Atp6v1a1 & ATPase, $\mathrm{H}$ transporting, $\mathrm{V}_{1}$ subunit $\mathrm{A}$, isoform 1 & 1.96 & Proton transport \\
\hline Ctsa & Cathepsin A & 2.17 & Proteolysis \\
\hline Stat1 & Signal transducer and activator of transcription 1 & 1.56 & Transcription \\
\hline Oas1a & $2 ', 5^{\prime}$-Oligoadenylate synthetase $1 \mathrm{~A}$ & 1.61 & Negative regulation of viral reproduction \\
\hline Ddx58 & DEAD box polypeptide 58 & 1.90 & Immune response \\
\hline Tmem154 & Transmembrane protein 154 & 1.76 & Not defined \\
\hline Fcgrt & Fc receptor, lgG, alpha chain transporter & 1.41 & Immune response \\
\hline $\operatorname{ltm} 2 b$ & Integral membrane protein $2 \mathrm{~B}$ & 2.45 & Induction of apoptosis \\
\hline Sema6a & $\begin{array}{l}\text { Sema domain, transmembrane domain and cytoplasmic } \\
\text { domain (semaphorin) } 6 \mathrm{~A}\end{array}$ & 1.52 & Cell differentiation/apoptosis \\
\hline Cuedc1 & CUE domain containing 1 & 1.54 & Not defined \\
\hline Rtp4 & Receptor transporter protein 4 & 1.96 & Not defined \\
\hline
\end{tabular}

Genes that increase strongly upon initiation of differentiation. 2 logFC denotes the 2 log of fold-change (a value of 2 equals a fourfold upregulation or a $400 \%$ increase during differentiation).

cell-like, of which we here suggest several candidates, could be important for diagnosis and treatment decisions.

Further, in the transcriptome analysis we observed a relation between mammary stem-like cell differentiation and regulation of skeletal development genes (including osteoblastic stem cell markers Spark and Spp1 [30]). In addition, both II6, which functions as a differentiation regulator of preosteoblast cells [46], and the corresponding downstream osteoblast-specific differentiation marker Runx2 decreased when stem-like cells entered differentiation, and Ocil, a negative regulator of oste- oclast differentiation, showed a robust increase at both differentiation stages. This finding may indicate why breast tumors have a preference for skeletal metastases, and these genes may have a potential as metastasis markers. Indeed, other genes implicated in bone metastasis of breast cancer cells (Ctfg, Fst and Dusp1 [47] and Adamts1 [47,48]) were altered during the differentiation of mammary stem-like cells. Expression of Adamts 1 at the protein level is also shown in Figure $2 d$ as elevated at the stem-like cell stage. In addition, lung metastasis gene expression also has an apparent parallel to stem cell-like gene expression (Table 6); lung metastasis signature 
Table 3

\begin{tabular}{|c|c|c|}
\hline & No genes & EASE score \\
\hline \multicolumn{3}{|l|}{ Over-represented in stem-like cells } \\
\hline Cell cycle & 90 & $3.6 \times 10^{-27}$ \\
\hline DNA metabolism & 72 & $1.7 \times 10^{-23}$ \\
\hline RNA metabolism & 45 & $3.2 \times 10^{-12}$ \\
\hline Regulation of cell cycle & 36 & $1.8 \times 10^{-7}$ \\
\hline Chromatin assembly/disassembly & 14 & $2.0 \times 10^{-5}$ \\
\hline Protein amino acid phosphorylation & 34 & 0.008 \\
\hline Protein metabolism & 118 & 0.01 \\
\hline \multicolumn{3}{|l|}{ Under-represented in stem-like cells } \\
\hline Coenzyme metabolism & 15 & 0.0003 \\
\hline Cell adhesion & 38 & 0.0007 \\
\hline Vesicle-mediated transport & 20 & 0.003 \\
\hline Lipid metabolism & 31 & 0.004 \\
\hline Epithelial cell differentiation & 4 & 0.005 \\
\hline Regulation of apoptosis & 15 & 0.005 \\
\hline Cell differentiation & 19 & 0.03 \\
\hline Skeletal development & 10 & 0.05 \\
\hline Regulation of transcription, DNA dependent & 72 & 0.13 \\
\hline
\end{tabular}

Biological function as defined by gene ontology. The stem-like cell gene expression is compared with expression in the pre-differentiated stage. Expression Analysis Systematic Explorer (EASE) score: modified Fischer exact probability $t$ test.

genes [38]) change considerably during differentiation, most of them being elevated at the stem cell-like stage - for example, the cytokine angiopoietin-like 4, shown to prime breast cancer cells for lung metastasis [49]. The correlation of stem cell-like gene expression to metastasis signatures may in part explain the above correlation to poor prognosis.

Our approach using cross-species comparisons of murine mammary stem cell-like expression and human tumor gene expression to unlock evolutionarily conserved breast cancerstem cell networks has provided highly concordant observations. Furthermore, this approach recently gained support, as cross-species comparisons were shown to be a powerful means of identifying essential connections [50].

\section{Mammary stem-like cell differentiation compared with in vivo mammary gland}

We were interested to see whether the changes observed during stem-like cell differentiation showed any resemblance to the in vivo mammary gland differentiation, keeping in mind that in the mammary gland the stem cells only constitute a minority of all cells, and that their gene expression is likely to be masked by changes in other cells as well as by changes in the relative proportions of different cell types. The cellular three-dimensional structure, interaction with stroma and in vitro versus in vivo signaling, also makes the two systems very different. We compared mRNA levels of $\mathrm{HC} 11$ cells with 2month-old virgin, pregnant and lactating mammary glands, where the proliferating stage could be compared with the actively proliferating pregnant mammary gland. Genes that were overexpressed at the stem cell-like stage (Birc5, Areg, Ereg, Cyclin D, Lif and Hist1h1a) all had increased expression in the pregnant glands but decreased their expression in the lactating glands (data available in Additional file 2). For the genes whose expression was low at the stem cell-like stage but was upregulated as the cells differentiated, several were also expressed at a low level in the virgin gland and were upregulated in pregnant and/or lactating gland (Expi, Ecad, Perp, Ehf, Nfat), whereas two genes (Msi2h and Mmp15) showed an opposite regulation and decreased during in vivo gland differentiation (Additional file 2). Although this comparison is relatively simplistic, our data indicate that stem cell-like proliferation is highest in the pregnant mammary gland whereas genes robustly expressed at terminal differentiation of $\mathrm{HC} 11$ cells are also highly expressed in the lactating mammary gland. 
Table 4

Correlation of mouse mammary stem-like gene expression and breast tumor prognosis signatures

\begin{tabular}{|c|c|c|}
\hline High at stem-like stage & Low at stem-like stage & Unchanged \\
\hline \multicolumn{3}{|c|}{ Poor prognosis: 37 genes, 22 of which (59\%) changed in stem-like stage } \\
\hline 17 genes & 5 genes & 15 genes \\
\hline Melk - protein phosphorylation & Gpr126 - neuropeptide signaling pathway & Tmeff1 - development \\
\hline Diap3 - cytoskeleton organization & Akap2 - unknown function & Exoc7 - protein transport \\
\hline Ext1 - ossification & Oxct1 - metabolic process & Slc2a3 - transmembrane transport \\
\hline Ect2 - signaling cascade & $\begin{array}{l}\text { Fbxo31 - ubiquitin-dependent protein catabolic } \\
\text { process }\end{array}$ & Lpcat1 - metabolic process \\
\hline $\begin{array}{l}\text { Uchl5 - ubiquitin-dependent protein catabolic } \\
\text { process }\end{array}$ & Igfbp5 - regulation of cell growth & Egln1 - oxygen homeostasis \\
\hline DC13 - unknown function & Esm1 - regulation of cell growth & Pitrm1 - proteolysis \\
\hline Gmps - purine base biosynthetic process & & Cdc42bpa - protein phosphorylation \\
\hline Dck - pyrimidine nucleotide metabolic process & & Gpr180 - unknown function \\
\hline Rcf4 - DNA replication & & Mmp9 - regulation of apoptosis \\
\hline Orc6I - DNA replication & & Hrasls - regulation of cell growth \\
\hline Dtl - DNA replication & & Flt1 - regulation of cell proliferation \\
\hline \multicolumn{3}{|l|}{ Cenpa - nucleosome assembly } \\
\hline \multicolumn{3}{|l|}{ Prc1 - cell cycle } \\
\hline \multicolumn{3}{|l|}{ Ccne2 - cell cycle } \\
\hline \multicolumn{3}{|l|}{ Kntc2 - cell cycle } \\
\hline \multicolumn{3}{|l|}{ Mcm6 - cell cycle } \\
\hline Nusap1 - cell cycle & & \\
\hline
\end{tabular}

Good prognosis: 12 genes, none of which (0\%) changed in stem-like stage

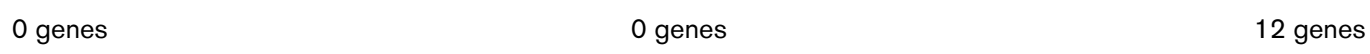

Ap2b1 - protein transport
Ms4a7 - signal transduction
Stk32b - protein phosphorylation
Scube2 - calcium ion binding
Aldh4a1 - proline catabolic process
Gstm3 - metabolic process
Peci - metabolic process
Ebf4 - regulation of transcription
Bbc3 - induction of apoptosis
Tgfb3 - cell growth/signal transduction
Fgf18 - regulation of cell proliferation
Wisp1 - regulation of cell growth

From van't Veer et al. [43]. Names and biological process (as defined by gene ontology, selected and/or abbreviated to fit table) are provided. 
Table 5

Correlation of mouse mammary stem-like gene expression and breast subtype signatures

\begin{tabular}{|c|c|c|}
\hline High at stem-like stage & Low at stem-like stage & Unchanged \\
\hline \multicolumn{3}{|c|}{ Normal breast-like (ER-negative): 10 genes, none of which (0\%) changed in stem-like stage } \\
\hline \multirow[t]{11}{*}{0 genes } & 0 genes & 10 genes \\
\hline & & Fhl1 - cell differentiation \\
\hline & & Cd36 - cell adhesion \\
\hline & & Itga7 - cell adhesion \\
\hline & & Leprotl1 - unknown \\
\hline & & Gpx3 - oxidation reduction \\
\hline & & Gpd1 - oxidation reduction \\
\hline & & Aoc3 - oxidation reduction \\
\hline & & Lpl - lipid catabolic process \\
\hline & & Aqp7 - transport \\
\hline & & Cidec - apoptosis \\
\hline
\end{tabular}

Her2+ (ER-negative): four genes, one of which (25\%) changed in stem-like stage

1 gene 0 genes 3 genes

Traf4 - regulation of apoptosis

Erbb2 - cell proliferation

Grb7 - signal transduction

Smarce1 - chromatin modification

Luminal A (ER-positive, p53 mut): 13 genes, three of which (23\%) changed in stem-like stage

\begin{tabular}{|c|c|c|}
\hline 0 genes & 3 genes & 10 genes \\
\hline & ER $\alpha$ - regulation of transcription & Gata3 - regulation of transcription \\
\hline & Myo6 - regulation of transcription & Foxa1 - regulation of transcription \\
\hline & Xbp1 - regulation of transcription & Aff3 - regulation of transcription \\
\hline & & Npnt - cell adhesion \\
\hline & & Anxa9 - cell - cell adhesion \\
\hline & & Gpr160 - signal transduction \\
\hline & & Slc39a6 - ion transport \\
\hline & & Tff3 - defense response \\
\hline & & Acadsb - lipid metabolic process \\
\hline & & Nat1 - metabolic process \\
\hline \multicolumn{3}{|c|}{ Luminal C (ER-positive, p53 mut): eight genes, six of which (75\%) changed in stem-like stage } \\
\hline 5 genes & 1 genes & 2 genes \\
\hline Mybl2 - regulation of transcription & Ggh - glutamine metabolic process & Ywhaz - protein targeting \\
\hline Ybx1 - transcription & & Sqle - oxidation reduction \\
\hline \multicolumn{3}{|l|}{ Tfrc - endocytosis } \\
\hline \multicolumn{3}{|l|}{ Ebna1bp2 - unknown function } \\
\hline \multicolumn{3}{|l|}{ Kif23 - cell cycle } \\
\hline \multicolumn{3}{|c|}{ Basal like (ER-negative, p53 mut): 15 genes, nine of which (60\%) changed in stem-like stage } \\
\hline 5 genes & 4 genes & 6 genes \\
\hline Cdh3 - cell adhesion & Trim29 - transcription & Tnni2 - regulation of transcription \\
\hline Lamc2 - cell adhesion & Slpi - serine - type endopeptidase inhibitor activity & Nfib - regulation of transcription \\
\hline Krt17 - epidermis development & Galnt3 - metabolic process & Capn6 - proteolysis \\
\hline Krt5 - epidermis development & Sox9 - transcription/regulation of cell proliferation & Dmd - peptide biosynthetic process \\
\hline \multirow[t]{2}{*}{ Cxcl1 - negative regulation of cell proliferation } & & Tgfb2 - apoptosis \\
\hline & & Fabp7 - regulation of cell proliferation \\
\hline
\end{tabular}

From Sorlie et al.[10]. Names and biological process (as defined by gene ontology, selected and/or abbreviated to fit table) are provided. ER, estrogen receptor. 
Correlation of mouse mammary stem-like gene expression and published breast tumor lung metastasis signatures

Lung metastasis signature: 14 genes, nine of which (64\%) changed in stem-like stage

\begin{tabular}{|c|c|c|}
\hline High at stem-like stage (9 genes) & Low at stem-like stage ( 0 genes) & Unchanged (5 genes) \\
\hline Id1 - regulation of transcription & & Kynu - metabolic process \\
\hline Tnc - cell adhesion & & Man1a1 - metabolic process \\
\hline Ly6e $\mathrm{e}^{\mathrm{a}}$ - cell surface receptor-linked signal transduction & & Vcam1-membrane to membrane docking \\
\hline Ltbp1 - growth factor binding & & Cxcr4 - apoptosis \\
\hline Angpt|4a - regulation of apoptosis & & Nedd9 - cell cycle/cell adhesion \\
\hline \multicolumn{3}{|l|}{ Ptgs 2 - regulation of cell proliferation } \\
\hline \multicolumn{3}{|l|}{ Cxcl1 - negative regulation of cell proliferation } \\
\hline \multicolumn{3}{|l|}{ Ereg - regulation of mitosis } \\
\hline Fscn1 - cell proliferation & & \\
\hline
\end{tabular}

From Minn et al. [38]. Names and biological process (as defined by gene ontology, selected and/or abbreviated to fit table) are provided. aHigh in pre-differentiated stage only.

Among the nuclear receptors, we found that COUP-TFII and NURR1 decreased during differentiation of the HC11 cells and in the transition from pregnant to lactating mammary gland. ER $\beta$ and VDR, both suggested to be protective in breast cancer $[8,40,51]$, were further induced in differentiated (lactating) mammary gland compared with virgin gland, whereas ER $\alpha$ - which is often increased in breast cancers was reduced. Comparison of a published study of in vivo mouse mammary glands, investigating 10-week nulliparous mammary glands and 18-day pregnant glands [52], with our data on $\mathrm{HC} 11$ cellular differentiation shows that as many as 279 genes changed in $\mathrm{HC} 11$ stem-like cells were also changed in the pregnant mammary gland, further showing that there is numerous correlations between the in vitro and in vivo systems in terms of differentiation.

\section{Conclusions}

The aim of the present study was to characterize the differentiation process of the stem cell-like $\mathrm{HC} 11$ cell line and to define the transcriptome of proliferating undifferentiated mammary epithelial stem cell-like cells, in relation to their differentiated counterparts. This provides a basis for research on mammary stem cells; both known and novel stem cell gene expression characteristics were found. Characterized mammary stem cell markers are highly needed, and several potentially suitable targets detected in our study will be valuable to investigate further.

We explored whether there is a link between mammary stemlike cell gene expression and that of breast cancer. The present study was performed using an in vitro system of mammary stem-like cell differentiation. In vitro systems have drawbacks, and rarely fully resemble the in vivo situation, but can nonetheless yield significant information. We found an interesting correlation between the pattern of stem-like cell expres- sion and that of human breast cancer with poor prognosis, metastasis and tumor subtypes. This may indicate that some breast tumors have a high ratio of cancer stem cells, and may require specific and aggressive treatment. An amount of novel gene expression data is presented, with implications for stem cell and mammary gland development biology and breast cancer research. A scheme is provided where key differences between differentiation steps can be dissected. We conclude that $\mathrm{HC} 11$ cells are relevant for studying mammary stem cells, their differentiation and their relationship to breast cancer.

\section{Competing interests}

The authors declare that they have no competing interests.

\section{Authors' contributions}

$\mathrm{CW}$ conceived of the study and participated in the design and coordination, carried out the transcriptome studies, real-time PCR analysis, bioinformatic analysis and comparisons, and drafted the manuscript. $\mathrm{LH}$ participated in the design, carried out the cell cultures, mammary gland tissue dissection and immunostainings, and helped to draft the manuscript. KE performed laboratory work and helped to draft the manuscript. L$\mathrm{AH}$ participated in the design of the study and helped to draft the manuscript. J-ÅG helped to draft the manuscript. All authors read and approved the final manuscript. 


\section{Additional files}

The following Additional files are available online:

\section{Additional data file 1}

Excel file containing a table that lists all differentially expressed genes detected in the microarray analysis. Gene symbol, gene name, GenBank, and changes between the different stages with corresponding statistical values are given in separate columns. See http://www.biomedcentral.com/content/ supplementary/bcr2256-S1.xls

\section{Additional data file 2}

Adobe file containing a figure that shows the real-time PCR confirmations of differentially expressed genes: confirmation of microarray results and correlating changes in in vivo mammary glands, of genes regulated during differentiation of $\mathrm{HC} 11$ cells.

See http://www.biomedcentral.com/content/ supplementary/bcr2256-S2.pdf

\section{Additional data file 3}

Adobe file containing a figure that shows the real-time PCR confirmations of differentially expressed genes: correlating changes in in vivo mammary glands, of genes regulated during differentiation of $\mathrm{HC} 11$ cells.

See http://www.biomedcentral.com/content/ supplementary/bcr2256-S3.pdf

\section{Additional data file 4}

Adobe file containing a figure that shows the real-time PCR confirmations of differentially expressed genes: expression of nuclear receptors and/or related genes increasing during $\mathrm{HC} 11$ mammary stem-like differentiation and correlating changes in vivo mammary glands.

See http://www.biomedcentral.com/content/ supplementary/bcr2256-S4.pdf

\section{Additional data file 6}

image file containing a figure that shows expression of vimentin analyzed by immunofluorescence in $\mathrm{HC} 11$ stem cell-like, pre-differentiated and differentiated cells.

See http://www.biomedcentral.com/content/ supplementary/bcr2256-S6.tiff

\section{Additional data file 7}

image file containing a figure that shows expression of the milk protein beta casein analyzed by immunofluorescence in $\mathrm{HC} 11$ stem cell-like, predifferentiated and differentiated cells. See http://www.biomedcentral.com/content/ supplementary/bcr2256-S7.tiff

\section{Additional data file 5}

Adobe file containing a figure that shows the real-time PCR confirmations of differentially expressed genes: expression of nuclear receptors and/or related genes decreasing during $\mathrm{HC} 11$ mammary stem-like differentiation and correlating changes in vivo mammary glands.

See http://www.biomedcentral.com/content/ supplementary/bcr2256-S5.pdf

\section{Acknowledgements}

The authors thank MSc Maria Berling for valuable assistance. The study was supported by grants from the Swedish Cancer Society, the Lars Hierta Memorial Foundation, the Magnus Bergvall Foundation, and the David and Britt Haydens Foundation.

\section{References}

1. Vaillant $F$, Asselin-Labat ML, Shackleton M, Lindeman GJ, Visvader JE: The emerging picture of the mouse mammary stem cell. Stem Cell Rev 2007, 3:114-123.

2. Stingl J, Eirew P, Ricketson I, Shackleton M, Vaillant F, Choi D, Li $\mathrm{HI}$, Eaves CJ: Purification and unique properties of mammary epithelial stem cells. Nature 2006, 439:993-997.

3. Polyak K: Breast cancer: origins and evolution. J Clin Invest 2007, 117:3155-3163.

4. Cobaleda C, Cruz J, Gonzalez-Sarmiento R, Sanchez-Garcia I, Perez-Losada J: The emerging picture of human breast cancer as a stem cell-based disease. Stem Cell Rev 2008, 4:67-79.

5. Visvader JE, Lindeman GJ: Cancer stem cells in solid tumours: accumulating evidence and unresolved questions. Nat Rev Cancer 2008, 8:755-768.

6. Kelsey JL, Gammon MD, John EM: Reproductive factors and breast cancer. Epidemiol Rev 1993, 15:36-47.

7. Britt K, Ashworth A, Smalley M: Pregnancy and the risk of breast cancer. Endocr Relat Cancer 2007, 14:907-933.

8. Williams C, Edvardsson K, Lewandowski SA, Strom A, Gustafsson $\mathrm{J}-\mathrm{A}$ : A genome-wide study of the repressive effects of estrogen receptor beta on estrogen receptor alpha signaling in breast cancer cells. Oncogene 2008, 27:1019-1032.

9. Warri A, Saarinen NM, Makela S, Hilakivi-Clarke L: The role of early life genistein exposures in modifying breast cancer risk. Br J Cancer 2008, 98:1485-1493.

10. Sorlie T, Perou CM, Tibshirani R, Aas T, Geisler S, Johnsen H, Hastie T, Eisen MB, Rijn M van de, Jeffrey SS, Thorsen T, Quist $H$, Matese JC, Brown PO, Botstein D, Lonning PE, Borresen-Dale A$\mathrm{L}$ : Gene expression patterns of breast carcinomas distinguish tumor subclasses with clinical implications. Proc Natl Acad Sci 2001, 98:10869-10874.

11. Ball RK, Friis RR, Schoenenberger CA, Doppler W, Groner B: Prolactin regulation of beta-casein gene expression and of a cytosolic $120-k d$ protein in a cloned mouse mammary epithelial cell line. EMBO J 1988, 7:2089-2095.

12. Humphreys R, Rosen J: Stably transfected $\mathrm{HC} 11$ cells provide an in vitro and in vivo model system for studying Wnt gene function. Cell Growth Differ 1997, 8:839-849.

13. Desrivières $S$, Prinz T, Castro-Palomino Laria N, Meyer M, Boehm G, Bauer U, Schafer J, Neumann T, Shemanko C, Groner B: Comparative proteomic analysis of proliferating and functionally differentiated mammary epithelial cells. Mol Cell Proteomics 2003, 2:1039-1054.

14. Desrivières S, Kuhn K, Müller J, Gläser M, Castro-Palomino LN, Korder J, Sonnentag M, Neumann T, Schwarz J, Schäfer J, Hamon C, Groner B, Prinz T: Comparison of the nuclear proteomes of mammary epithelial cells at different stages of functional differentiation. Proteomics 2007, 7:2019-2037.

15. Kendrick H, Regan J, Magnay F-A, Grigoriadis A, Mitsopoulos C, Zvelebil M, Smalley M: Transcriptome analysis of mammary epi- 
thelial subpopulations identifies novel determinants of lineage commitment and cell fate. BMC Genomics 2008, 9:591.

16. Smyth G K: Linear models and empirical Bayes methods for assessing differential expression in microarray experiments. Stat Appl Genet Mol Biol 2004, 3:article 3.

17. Hosack DA, Dennis JG, Sherman BT, Lane HC, Lempicki RA: Identifying biological themes within lists of genes with EASE. Genome Biol 2003, 4:R70.

18. Petersen $\mathrm{H}$, Haldosén L-A: EGF modulates expression of STAT5 in mammary epithelial cells. Exp Cell Res 1998, 243:347-358.

19. Weihan W, Bethanie M, Traci G, Cynthia CJ, Nicholas K, Cutler ML: Glucocorticoid induced expression of connective tissue growth factor contributes to lactogenic differentiation of mouse mammary epithelial cells. J Cell Physiol 2008, 214:38-46.

20. Cella N, Cornejo-Uribe RR, Montes GS, Hynes NE, Chammas R: The lysosomal-associated membrane protein LAMP-1 is a novel differentiation marker for $\mathrm{HC} 11$ mouse mammary epithelial cells. Differentiation 1996, 61:113-120.

21. Phillips $K$, Park M, Quarrie L, Boutinaud M, Lochrie J, Flint D, Allan G, Beattie J: Hormonal control of IGF-binding protein (IGFBP)5 and IGFBP-2 secretion during differentiation of the HC11 mouse mammary epithelial cell line. J Mol Endocrinol 2003, 31:197-208.

22. Nagaoka K, Tanaka T, Imakawa K, Sakai S: Involvement of RNA binding proteins AUF1 in mammary gland differentiation. Exp Cell Res 2007, 313:2937-2945.

23. Grolli S, Accornero P, Ramoni R, Donofrio G, Whitelaw CBA: Expression of c-myc is down-regulated as mouse mammary epithelial cells become confluent. Biochem Biophys Res Commun 1997, 239:566-569.

24. Liu S, Ginestier C, Charafe-Jauffret E, Foco H, Kleer CG, Merajver SD, Dontu G, Wicha MS: BRCA1 regulates human mammary stem/progenitor cell fate. Proc Natl Acad Sci 2008, 105:1680-1685.

25. Boecker W, Moll R, Dervan P, Buerger H, Poremba C, Diallo RI, Herbst $H$, Schmidt A, Lerch MM, Buchwalow IB: Usual ductal hyperplasia of the breast is a committed stem (progenitor) cell lesion. J Pathol 2002, 198:458-467.

26. Saito R, Tabata Y, Muto A, Arai K-i, Watanabe S: Melk-like kinase plays a role in hematopoiesis in the zebra fish. Mol Cell Biol 2005, 25:6682-6693.

27. Nakano I, Paucar AA, Bajpai R, Dougherty JD, Zewail A, Kelly TK, Kim KJ, Ou J, Groszer M, Imura T, Freije WA, Nelson SF, Sofroniew MV, Wu H, Liu X, Terskikh AV, Geschwind DH, Kornblum HI: Maternal embryonic leucine zipper kinase (MELK) regulates multipotent neural progenitor proliferation. J Cell Biol 2005, 170:413-427.

28. Andäng $M$, Hjerling-Leffler J, Moliner A, Lundgren TK, CasteloBranco G, Nanou E, Pozas E, Bryja V, Halliez S, Nishimaru $H$, Wilbertz J, Arenas E, Koltzenburg M, Charnay P, El Manira A, Ibañez CF, Ernfors P: Histone H2AX-dependent GABA(A) receptor regulation of stem cell proliferation. Nature 2008, 451:460-464

29. Srivastava N, Gochhait S, Gupta P, Bamezai RN: Copy number alterations of the H2AFX gene in sporadic breast cancer patients. Cancer Genet Cytogenet 2008, 180:121-128.

30. Krzyzanowski P, Andrade-Navarro M: Identification of novel stem cell markers using gap analysis of gene expression data. Genome Biol 2007, 8:R193.

31. Kurpios NA, MacNeil L, Shepherd TG, Gludish DW, Giacomelli AO, Hassell JA: The Pea3 Ets transcription factor regulates differentiation of multipotent progenitor cells during mammary gland development. Dev Biol 2009, 325:106-121.

32. Shackleton M, Vaillant F, Simpson KJ, Stingl J, Smyth GK, AsselinLabat ML, Wu L, Lindeman GJ, Visvader JE: Generation of a functional mammary gland from a single stem cell. Nature 2006 , 439:84-88.

33. The Wnt Homepage [http://www.stanford.edu/ rnusse/wntwin dow.html]

34. Richter K, Wirta V, Dahl L, Bruce S, Lundeberg J, Carlsson L, Williams C: Global gene expression analyses of hematopoietic stem cell-like cell lines with inducible Lhx2 expression. BMC Genomics 2006, 7:75

35. Hampson IN, Hampson L, Pinkoski M, Cross M, Heyworth CM, Bleackley RC, Atkinson E, Dexter TM: Identification of a serpin specifically expressed in multipotent and bipotent hematopoi- etic progenitor cells and in activated T cells. Blood 1997, 89:108-118.

36. Nakshatri $H$, Mendonca MS, Bhat-Nakshatri $P$, Patel NM, Goulet RJ, Cornetta K: The orphan receptor COUP-TFII regulates G2/ $M$ progression of breast cancer cells by modulating the expression/activity of p21WAF1/CIP1, cyclin $D_{1}$, and cdk2. Biochem Biophys Res Commun 2000, 270:1144-1153.

37. Le Dily F, Métivier R, Guéguen MM, Le Péron C, Flouriot G, Tas P, Pakdel F: COUP-TFI modulates estrogen signaling and influences proliferation, survival and migration of breast cancer cells. Breast Cancer Res Treat 2008, 110:69-83.

38. Minn AJ, Gupta GP, Siegel PM, Bos PD, Shu W, Giri DD, Viale A Olshen AB, Gerald WL, Massague J: Genes that mediate breast cancer metastasis to lung. Nature 2005, 436:518-524.

39. Kanai Ml, Okabe M, Hiromi Y: Seven-up controls switching of transcription factors that specify temporal identities of Drosophila neuroblasts. Dev Cell 2005, 8:203-213.

40. Cui Y, Rohan TE: Vitamin D, calcium, and breast cancer risk: a review. Cancer Epidemiol Biomarkers Prev 2006, 15:1427-1437.

41. Wicha MS, Liu S, Dontu G: Cancer stem cells: an old idea - a paradigm shift. Cancer Res 2006, 66:1883-1890.

42. Gong Y, Symmans WF, Pusztai L: Gene-expression microarrays provide new prognostic and predictive tests for breast cancer. Pharmacogenomics 2007, 8:1359-1368.

43. van't Veer $L$, Dai $H$, Vijver MJ van de, He YD, Hart AAM, Mao M, Peterse HL, Kooy K van der, Marton MJ, Witteveen AT, Schreiber GJ, Kerkhoven RM, Roberts C, Linsley PS, Bernards R, Friend SH: Gene expression profiling predicts clinical outcome of breast cancer. Nature 2002, 415:530-536.

44. Yehiely F, Moyano JV, Evans JR, Nielsen TO, Cryns VL: Deconstructing the molecular portrait of basal-like breast cancer. Trends Mol Med 2006, 12:537-544.

45. Ben-Porath I, Thomson MW, Carey VJ, Ge R, Bell GW, Regev A, Weinberg RA: An embryonic stem cell-like gene expression signature in poorly differentiated aggressive human tumors. Nat Genet 2008, 40:499-507.

46. Li Y, Bäckesjö C-M, Haldosén L-A, Lindgren U: IL-6 receptor expression and IL-6 effects change during osteoblast differentiation. Cytokine 2008, 43:165-173.

47. Kang Y, Siegel PM, Shu W, Drobnjak M, Kakonen SM, CordónCardo C, Guise TA, Massagué J: A multigenic program mediating breast cancer metastasis to bone. Cancer Cell 2003, 3:537-549.

48. Liu YJ, Xu Y, Yu Q: Full-length ADAMTS-1 and the ADAMTS-1 fragments display pro- and antimetastatic activity, respectively. Oncogene 2006, 25:2452-2467.

49. Padua D, Zhang XH, Wang O, Nadal C, Gerald WL, Gomis RR, Massagué J: TGF $\beta$ primes breast tumors for lung metastasis seeding through angiopoietin-like 4. Cell 2008, 133:66-77.

50. Bennett C, Green J: Unlocking the power of cross-species genomic analyses: identification of evolutionarily conserved breast cancer networks and validation of preclinical models. Breast Cancer Res 2008, 10:213.

51. Palmieri C, Cheng G, Saji S, Zelada-Hedman M, Warri A, Weihua Z, Van Noorden S, Wahlstrom T, Coombes R, Warner M, Gustafsson J: Estrogen receptor beta in breast cancer. Endocr Relat Cancer 2002, 9:1-13.

52. Wang $M$, Master $S$, Chodosh L: Computational expression deconvolution in a complex mammalian organ. BMC Bioinformatics 2006, 7:328. 